\title{
Focusing on Food Security or Targeting the Economy: A Study on Maize and Cotton Production in Kandi Commune
}

\author{
Fabrice K Dossa*, Christian T Todota and Yann ES Miassi \\ Department of Economics and Rural Sociology, University of Parakou, Benin
}

Received: 眥July 23, 2018; Published: 眥July 31, 2018

*Corresponding author: Fabrice K Dossa, Department of Economics and Rural Sociology, Faculty of Agronomy, University of Parakou, BP 123, Parakou, Benin

\begin{abstract}
Maize and cotton are two crops that are highly produced in North Benin. Their production has advantages as well as constraints. These advantages and constraints are considered in the choice of the producer to cultivate one of them. The objective of this study is to present, at first, the advantages and constraints that the producers of Kandi commune face on these two crops. It also aims to expose the producers' preference according to the advantages and constraints listed by them. To achieve this, the data were collected in two districts of the municipality over a period of two weeks. Semi-structured interviews were conducted with fifty producers through an interview guide. Data processing was carried out using a dual approach (quantitative and qualitative) which, on the one hand, consisted in carrying out statistical tests and, on the other hand, analyzing the statements collected during the data collection. The main statistical test used in this study is Kendall's W-concordance test, which has been used to prioritize constraints. At the end of the analyses, it appears that cotton, just like corn, enables producers to meet the needs and social development of their households. On the other hand, the non-organization of the maize sector, the lack of inputs and the delay in their distribution, maize prices fluctuation and difficulties in the evacuation of cotton are the main constraints reported by producers. Despite its lack of organization and the other constraints to which it is subject, maize crop is the most preferred. In view of this, it would be appropriate to consider the organization of the maize sector and the optimization of the services provided by the organizations in charge of the cotton sector. This will be beneficial to both production systems and to all actors involved.
\end{abstract}

Keywords: Food security; Income; Advantages; Constraints; Farmer's choice

\section{Introduction}

Agriculture is one of the crucial activities that human being cannot neglect for his survival. It keeps the human species alive and contributes to its evolution. In Benin, it plays a great role in strengthening the economy and provide about $75 \%$ of jobs [1]. Among all the crops produced in the territory, two prove to be vital both in the constitution of the national economy and in the fight for food security: Those are corn and cotton. Known as the main cash crop in Benin [2] and the engine of the Beninese economy [3], cotton alone counts for $27 \%$ of exports and contributes by $7 \%$ to the national GDP. Its production has not stopped growing over the last five years. It reached in 2016, a tonnage of 451,000, which is an increase of more than $70 \%$ from the year 2015 [4]. Due to its multiple outlets, the cotton sector remains the country's best organized sector [5].

If cotton receives a lot of attention from the Beninese government, corn itself does not have such a privilege. Nevertheless, it is the crop that could be an alternative to cotton production [6] in northern Benin. It comes second, after cotton as a subsistence and cash crop [7]. Indeed, its cultivation occupies nearly $70 \%$ of the total area devoted to cereals in Benin and represents about $75 \%$ of cereal production [8]. Together with cowpea, cassava and yam, it forms the staple crops of people's diet [9]. Studies have shown that $63.1 \%$ of households in Benin consume 7 days out of 7 , maize being the main cereal in the food ration $[9,10]$. Apart from the aspects raised, corn also has medicinal properties. According to [11], the corncob is used in combination with other plants to cure knee and low back pain. Some use it to treat diseases such as malaria.

These two crops certainly have many advantages; however, the constraints meet by the producers in their manoeuver are not negligible. There is a serious but silent competition between the two crops. Competition in which one seems to have resources than the second more vulnerable. The purpose of this study is to 
present the advantages and constraints of the production of these two crops. Two aspects that remain decisive in the choice of the peasants to cultivate one of the two crops. The study also aims to exhibit between the two crops the most preferred by the farmers.

\section{Material and Methods Study Area}

The study took place in the municipality of Kandi, countytown of the department of Alibori. Located in the agro ecological zone of the cotton pan, it is limited by the communes of Malanville (North), Gogounou (South) Segbana (East) and Banikoara (West). It is spread out an area of $3421 \mathrm{Km} 2$ and includes ten districts, sixty-seven villages and fifteen districts. The climate in Kandi is of Sudanese type characterized by two seasons that follow each other: The first, rainy from May to October and the second, dry from November to April. Climate change in sub-Saharan Africa does not leave the Kandi commune on the side-lines. It is worth noting since a few decades in the commune and its surroundings an early drying up and a late or sometimes violent arrival of rains. Several studies carried out in the region have noted this [12-15]. In addition, the soil found at Kandi is of tropical ferruginous type.

The relief is made up of plateau and one distinguishes by place hills made of granites and quartzite. As for vegetation, the town has grassy savanna, shrub and trees with some gallery forests. In terms of agricultural production, Kandi has a good reputation coming in second place after Banikoara, the giant cotton supplier in Benin. Apart from this asset, the municipality is essential in the department in terms of corn production. The following Table 1 gives an idea of the evolution of these two crops from 2011 to 2016. Analysis of this table shows a peak of cotton and maize production between 2014 and 2016 with a respective tonnage of 48853.09 and 102240. The respective average production of the two crops is 362681.86 and 66394.68 tons.

Table 1: Production in tons of the last five years.

\begin{tabular}{|c|c|c|c|c|c|}
\hline \multicolumn{7}{|c|}{ Production in tons of the last five years } \\
\hline Crop & $\begin{array}{c}2011- \\
2012\end{array}$ & $\begin{array}{c}2012- \\
2013\end{array}$ & $\begin{array}{c}2013- \\
2014\end{array}$ & $\begin{array}{c}2014- \\
2015\end{array}$ & $\begin{array}{c}2015- \\
2016\end{array}$ \\
\hline Cotton & 25855.27 & 29595.08 & 36487.56 & 48853.09 & 40549.93 \\
\hline Maize & 59750.60 & 48577.80 & 51908 & 69497 & 102240 \\
\hline \multicolumn{7}{|c|}{ Apc $=36268.186$ Apm $=66394.68$} \\
\hline
\end{tabular}

Source: Municipal Development Plan, 2017.

\section{Methodological approach}

Among the ten districts of Kandi commune, only two were chosen to shelter the study. These are the districts of Angaradebou and Sonsoro. This choice was made in a participatory way with the coordinator of the Interprofessional Association of Cotton Producers. Firstly because of their performance in the production of both crops within the municipality and secondly because of their positioning. This choice was made for a wide variation of collected data and the obtaining of a socio-cultural diversity to better touch the realities of the producers of Kandi as a whole.

The data was collected using an interview guide designed to collect qualitative and quantitative data. The collection took place during the month of April of the year two thousand and eighteen (2018) and lasted 2 weeks. After an individual interview with five producers, the questionnaire underwent a slight adjustment. Faced with the unavailability of some farm managers, other people who were relatively close to them and involved in the farming activities of the households proved to be able to provide the necessary information for the study. A total of 25 subjects per district producing maize and cotton were included in the study. These have been identified by secretaries of cooperatives who hold leadership positions within their community. The following Table 2 provides an overview of the structure of the sample considered in the study.

Table 2: Structure of the study sample.

\begin{tabular}{|c|c|c|}
\hline District & $\begin{array}{c}\text { Producers } \\
\text { cooperative }\end{array}$ & $\begin{array}{c}\text { Number of } \\
\text { respondent }\end{array}$ \\
\hline \multirow{4}{*}{ Angaradebou } & Angaradebou1 & 5 \\
\cline { 2 - 3 } & Angaradebou3 & 10 \\
\cline { 2 - 3 } & Angaradebou4 & 10 \\
\hline \multirow{5}{*}{ Sonsoro } & Ankouamon & 7 \\
\cline { 2 - 3 } & Deeman & 3 \\
\cline { 2 - 3 } & Sinawongou Peuhl & 2 \\
\cline { 2 - 3 } & Sinawongou Baka & 8 \\
\cline { 2 - 3 } & SonsoroB1 & 5 \\
\hline
\end{tabular}

Source: Survey Results, Kandi 2018.

\section{Data analysis}

The data capture and analysis were carried out exclusively with SPSS v21.0 32bits software. The data processing was done using descriptive statistics, speech analysis and Kendall's W-concordance test. The descriptive statistics essentially allow to obtain the frequencies and average of variables characterizing from a social and demographic point of view the interviewed farmers. The comments received from producers were analyzed and then used to model the "benefits and constraints" section. This technique was chosen inspired by the work of several authors including [1618]. The Kendall's W-concordance test was also used to prioritize production constraints in order of importance.

\section{Results}

Table 3 below summarizes the socio-demographic characteristics of the producers surveyed in this study. It indicates that the subjects included in the sample are predominantly male (90\%) with a low representation of women (10\%). Ninety-four per cent of them live entirely depending on agriculture, compared to six per cent who make it as a secondary activity. Their farming experience varies from 3 to 40 years with an average of 16.92 
years. Compared to the size of farm households in both localities (13 persons), the average number of farm active worker (7 approximately) is relatively small. Farmers send their children to school until they are unable to move on. Sixty percent received formal education and forty percent got literate in local languages. Among those who have been literate $22 \%$ hold the certificate of primary school, $10 \%$ hold the certificate of secondary school and $2 \%$ hold the high school diploma and bachelor's degree. Anyone wishing to cultivate cotton is required to belong to a Village Cooperative of Cotton Producers, this justifies the membership to an organization unanimously own by the respondents. The average area of cotton planted is 6.62 ha on an average total area of 15.62 ha. In contrast, the average area of maize grown is 5.69 ha. An observation of these figures allows to say that the cotton takes with a small difference, the top on the corn in terms of cultivated area in the commune. This could be explained by the several constraints faced by corn producers. Note that these results are quite like those obtained by [19] in their studies in the same commune. Advantages related to cotton production.

Table 3: Socio-demographic characteristics.

\begin{tabular}{|c|c|c|}
\hline Qualitative Variables & Modalities & $\begin{array}{c}\text { Relative frequencies } \\
\text { (\%) }\end{array}$ \\
\hline \multirow{2}{*}{ Sex } & M & 90 \\
\hline & $\mathrm{F}$ & 10 \\
\hline \multirow{2}{*}{ Access to credit } & Yes & 50 \\
\hline & No & 50 \\
\hline \multirow{3}{*}{ Main activities } & Agriculture & 94 \\
\hline & Teaching & 4 \\
\hline & Masonry & 2 \\
\hline \multirow{2}{*}{ Formal education } & Yes & 60 \\
\hline & No & 24 \\
\hline \multirow{2}{*}{$\begin{array}{c}\text { Literacy in local } \\
\text { language }\end{array}$} & Yes & 46 \\
\hline & No & 54 \\
\hline \multirow{2}{*}{$\begin{array}{l}\text { Organization } \\
\text { membership }\end{array}$} & Yes & 100 \\
\hline & No & 0 \\
\hline Quantitative variables & Average & Standard deviation \\
\hline Age & 38.16 & 9.97 \\
\hline $\begin{array}{c}\text { Average size of } \\
\text { household }\end{array}$ & 13.22 & 8.46 \\
\hline $\begin{array}{c}\text { Number of } \\
\text { farmworkers }\end{array}$ & 6.74 & 5.63 \\
\hline Year of experience & 16.92 & 9.76 \\
\hline Total area planted & 15.42 & 9.53 \\
\hline Area under cotton & 6.62 & 4.94 \\
\hline Area under corn & 5.69 & 3.35 \\
\hline
\end{tabular}

Source: Survey Results, Kandi 2018.

Cotton plays a major role in the lives of Kandi producers. From the exchanges held with the 50 people surveyed, it appears that several benefits are derived from the production of cotton. It allows heads of households and farms to make investments (buying cattle for traction, rolling stock, building houses), to perform ceremonies (marriage, baptism, burial) and then to meet regular expenses in their households and farms (schooling, food, expenses and debts of agricultural campaigns). The Interprofessional Cotton Association known as "AIC" is the structure in charge of the cotton sector throughout the national territory. It has set in place a mechanism that allows producers to get inputs on credit before the campaign. They receive the inputs on credit, use them for production, and subsequently pay their debts at the time of payment. This approach is appreciated by the producers because, they lack sufficient financial means at the time of starting the campaign. Through the comments transcribed below, two producers support what has been said above.

"The cash of cotton appears for me like a tontine, it allowed me to buy my bike, to build the house where I live. Thanks to the cotton I bought a ginning machine that serves me a lot after the corn harvest. My eldest son is already old enough to marriage. I need to buy him a motorcycle and prepare for his wedding by next year. It is on the cash of the cotton that I count to be able to do it". "The cash we get from cotton also allows us to do ceremonies. It is an obligation for us. In our culture, when someone close to your family dies, that means that your money is dying too. You cannot have money hidden somewhere without doing it. It's like a duty for us".

\section{Advantages Related to Maize Production}

Corn in the first place ensures the food needs of households and the farm. After production, much of the crop is set aside to allow the producer, his family and those who serve him to overcome hunger, one of Maslow's primary human needs. In the same way, the seeds used by the producers are taken from the previous crops. Apart from these two aspects, a great part of the producers has said that corn helps them financially. In fact, after harvest they reserve a larger portion for commercial purposes. The main reason behind this, is to cover regular expenses and household contingencies. These unforeseen events are usually cases of illness or death. Growing maize for the farmer is therefore a way to keep his relatives in safe from the food and financial point of view. The comments collected on this issue were analyzed and reissued below. "Corn helps us a lot, that's what we eat at home almost all the time. In the form of dough, boiled, and akassa (local meal made with corn). When we are facing a financial problem we just have to take a bag of maize, sell it and the problem is solved". "Cotton's cash lasts before coming. All the while, it's corn that keeps us alive. Corn helps us a lot without lying to you".

\section{Cotton production constraints}

The benefits of cotton and corn production are enormous. However, during the survey, producers listed several constraints 
they face every day. Seven main constraints came back during the exchanges. They have been grouped in the following Table 4 with their respective average ranks. It is noted after analysis of the Table 5 that the main constraint reported by the population studied is the insufficiency of the seeds supplied to them. Most producers have not only deplored the lack of seeds but also the late availability of these inputs. Similarly, the removal of seed cotton, the late payment of cotton costs, the inadequacy of herbicides and the high cost of inputs are the secondary constraints recorded in this study. It is also important to note through the Kendall coefficient (0.379) that the order of importance of these constraints varies quite remarkably from one producer to another.

Table 4: Classification of constraints related to cotton production.

\begin{tabular}{|c|c|}
\hline Constraints & Average ranks \\
\hline Insufficiency of seed & 1.88 \\
\hline Difficulty of evacuating cotton & 4 \\
\hline Delay in income payment & 4.08 \\
\hline Herbicide insufficiency & 4.33 \\
\hline High price of output & 4.96 \\
\hline Lack of financial mean for the \\
harvest & 5.54 \\
\hline Irregularity of rains & 6.17 \\
\hline Difficulty of accessing the & 6.38 \\
\hline workforce & 7.67 \\
\hline Difficulty of insecticide treatment & \\
\hline
\end{tabular}

Kendall's W-coefficient of concordance $=0.379 \mathrm{p}=0.000015$

Source: Survey Results, Kandi 2018.

Table 5: Classification of constraints related to corn production.

\begin{tabular}{|c|c|}
\hline Constraints & Average ranks \\
\hline Lack of inputs & 1.20 \\
\hline Maize sellout & 2.50 \\
\hline Lack of financial mean & 2.70 \\
\hline Lack of agricultural equipment & 4.20 \\
\hline Fluctuation of maize price & 4.40 \\
\hline
\end{tabular}

Kendall's W-coefficient of concordance $=0.698 \mathrm{p}=0.000013$

Source: Survey Results, Kandi 2018.

\section{Corn production constraints}

Concerning corn production constraints, there is a relatively high degree of agreement on the ranking (Kendall's coefficient $=0.698$ ). The first three constraints recorded are the lack of specific inputs for maize, the obligation to sell cheap the crops, and the lack of financial means to cover the expenses inherent to production. The lack of agricultural equipment and the fluctuation of the price of maize occupy the last places in this ranking.

\section{Corn or Cotton}

The objective of this section is to expose the respondents' position after having simulated a situation where they are faced with making a choice between the two crops. It also aims to explain the reasons justifying their respective positions. Table 6 presents the distribution of producers according to the crop chosen. From this table, it appears that more than half of the producers (58\%) chose corn, $22 \%$ cotton and $20 \%$ decided not to take a position. Table 7 below is a summary of the reasons given by the producers following the choice made. Producers, who opted for cotton justify their choice by the fact that the sector is organized, the price is stable, and inputs are provided on credit. At the same time, those who chose maize justify this by its ability to cope with the producer's financial problems, its ability to keep them alive before the arrival of cotton revenue and by its easiness and short production cycle. Producers who have maintained a neutral stance argue that the two crops are inseparable and that in the current context, corn production is necessary to reap the benefits of cotton.

Table 6: Crop chosen by farmers.

\begin{tabular}{|c|c|c|}
\hline Modalities & Number & $\begin{array}{c}\text { Relative frequencies } \\
\text { (\%) }\end{array}$ \\
\hline Maize & 29 & 58.0 \\
\hline Cotton & 11 & 22.0 \\
\hline Neutral & 10 & 20.0 \\
\hline
\end{tabular}

Source: Survey Results, Kandi 2018.

Table 7: Summary of the reasons given by the producers following the choice made.

\begin{tabular}{|c|c|c|}
\hline \multicolumn{3}{|c|}{ Farmer stances } \\
\hline Cotton & Corn & Neutral \\
\hline $\begin{array}{l}\text { Avaibility of cedit- } \\
\text { inputs }\end{array}$ & $\begin{array}{c}\text { Corn is easier to } \\
\text { cultivate }\end{array}$ & \\
\hline \multicolumn{3}{|l|}{$\begin{array}{c}\text { Than cotton. And the } \\
\text { production cycle is } \\
\text { shorter }\end{array}$} \\
\hline $\begin{array}{l}\text { The price of cotton } \\
\text { doesn't fluctuate as } \\
\text { corn }\end{array}$ & $\begin{array}{l}\text { Staple of the diet of } \\
\text { the households }\end{array}$ & \\
\hline $\begin{array}{c}\text { The cash of cotton } \\
\text { comes at }\end{array}$ & $\begin{array}{c}\text { Solve financial } \\
\text { problem benefits }\end{array}$ & $\begin{array}{l}\text { Corn and Cotton are } \\
\text { indissociable. It is } \\
\text { necessary to produce } \\
\text { corn to reap cotton } \\
\text { once. }\end{array}$ \\
\hline $\begin{array}{c}\text { The cotton sector is } \\
\text { organized corn sector } \\
\text { isn't }\end{array}$ & $\begin{array}{l}\text { Corn keeps farmers } \\
\text { alive before the arrival } \\
\text { of cotton income } \\
\text { while }\end{array}$ & \\
\hline
\end{tabular}

Source: Survey Results, Kandi 2018.

\section{Discussion}

As maize is a foodstuff, it is mainly used to cover the food needs of producers and their households. The forms under which it is 
consumed differ from one region to another, or even from one social category to another [20]. In Kandi commune, it is consumed in the form of porridge, paste and akassa. Secondarily, it is the subject of a commercial transaction and generates significant income for producers. After discussions with these producers, it is noted that the income earned is used for security purposes and social fulfilment. Purchases of food, buildings and ceremonies (marriage, baptism, death) are the main uses made of these incomes. They also, but very rarely, invest money that can add value to their production. Purchasing production equipment is generally limited to the minor tools that are necessary. This could be explained not only by the relatively large size of households living at the expense of these incomes, but also by the primacy of physiological and security needs over other needs.

The difficulties that undermine the maize sector in the municipality are enormous, as well as the benefits that result from it. The lack of specific maize inputs outweighs all constraints by unlawfully resorting to inputs for cotton production. According to $[5,7,21]$, this diversion is reflected in the low yields obtained at the cotton level. One could say that maize seems to be in the study area a parasite of the cotton crop. Studies conducted by [22] on the corn seed production and distribution system in accordance with this study revealed that the lack of input is one of the main weaknesses of the maize sector. The study also shows that, apart from the lack of inputs, the sale at low prices of harvests is a strategy developed by producers in urgent need of financial means. They are often lacking when they harvest the cotton. Cases of illness or other unforeseen events arise occasionally. In response to these problems, they sell corn crops. Those who do not adhere to this practice generally resort to Micro Finance Institutions (MFIs) loans as mentioned by [23]. The "warrantage", (a sort of securing by storing a part or the full harvest) implemented in Benin for more than a decade [24] in response to this situation hasn't unfortunately had a significant impact in the study area.

About cotton, it is noted that income from production has the same purpose as corn, with the difference that cotton is exclusively sold and used more for sustainable projects. In some localities in the study area, cotton producers pay contributions after receiving cotton income to build classrooms or other community infrastructures. Numerous producers greet the organization around the cotton sector and mainly the credit-input which is granted to them. This credit would allow them, according to [25], to effectively fight against pests and raise the level of fertility of their land. Nevertheless, the high cost of inputs, the insufficiency of seeds supplied and especially the delay in their delivery are denounced as the real handicaps of the sector. Many are forced to informally leave money to have the extra amount of seed needed. Added to this, the evacuation of cotton harvests from the production areas to the factory loses its nature of gratuity at a given period of the campaign. All these constraints call into question the performance of the production system.

\section{Conclusion}

The aim of this study was to shed light on the two most important agricultural value chains in northern Benin. This, through the advantages and constraints that characterize their productions. At the end of the study, it appears that cotton as much as maize represents a lot for farmers. Corn is the staple of their diet and significant revenues are derived from the production of both crops. These revenues are mainly used to meet the needs of households and their social development. Cotton, on the other hand, enables producers to meet their economic and social needs. Besides, the two production systems are subject to constraints that need to be considered for the betterment of these sectors and the actors involved. Giving common attention to both crops through the organization of the maize sector and the optimization of the services provided by the AIC are means likely to boost the satisfaction of all the actors involved.

\section{References}

1. Ministry of Agriculture (2013) Livestock and Fisheries, Performance Report on the Agricultural Sector, Management APRM. Cotonou, Benin.

2. VA Houndekon (2010) Comparative Analysis of Organic Cotton and Conventional Cotton Production Systems in Benin. pp. 13.

3. A Paraiso, AJ Yabi, A Sossou, N Zoumarou-Wallis, RN Yegbemey (2012) Economic and financial profitability of cotton production in Ouake in northwestern Benin. Ann Agron scientists 16(1): 91-105.

4. World Bank (2018) Benin Presentation.

5. HM Batamoussi, I Moumouni, J TOKORE OROU (2015) Contribution to the improvement of the farmers' practices of sustainable production of cotton (Gossypium hirsutum) in Benin: case of Banikoara commune. Int J Chem Sci 9(5): 2401-2413.

6. S Toukoudagba (2014) Economy of maize production in North Benin: an analysis of the income statement of agricultural holdings. Bulletin of Agronomic Research of Benin (BRAB) pp. 20-28.

7. MN Baco, T Abdoulaye, D Sanogo, A Langyintuo, Characterization of maize-producing households in the dry savanna zone of Benin.

8. Ministry of Agriculture (2010) Livestock and Fisheries, Strategic Plan for the Revival of the Agricultural Sector.

9. D Aly, HA Salami, Baba Moussa L, Y Chabi Gouro Biodiversity Management of Corn Crops in Benin. Res Gate, no. 4.

10. A Agbota, L Mahy, J Dossou Hessou (2009) Strategic Plan for the Development of Food and Nutrition.

11. HA Salami (2015) Biodiversity of local varieties of cultivation among farmers in Benin. pp. 15.

12. GL Djohy, E Boi Wosso, N Kinzo (2015) Climatic variability and cotton production in the commune of Kandi in North Benin. International Association of Climatology, Liege, Belgium, p. 6.

13. M Boko, F Kosmowski, E Wissin (2012) The challenges of climate change in Benin.

14. Ministry of the Environment and Nature Protection (2008) National Adaptation Program for Climate Change. 
15. MA Tidjani, PB Akponikpe (2012) Evaluation of the peasant strategies of adaptation to the climatic changes: Case of the Commune of Kandi in North-Benin. Afr Crop Sci J 20: 425-441.

16. C Altenbuchner, M Larcher, S Vogel (2016) The impact of organic cotton cultivation on the livelihood of smallholder farmers in Meatu district, Tanzania, Renewable Agriculture and Food Systems 31(1): 22-36.

17. C Altenbuchner, S Vogel, M Larcher (2017) Social, economic and environmental impacts of organic cotton production on the livelihood of smallholder farmers in Odisha, India. Renew Agric Food Syst 33(4): $1-13$.

18. F Dossa, Y Miassi, K Banzou (2018) Onion (Allium Cepa) Production in Urban and Peri-Urban Areas: Financial Performance and Importance of This Activity for Market Gardeners in Southern Benin. Curr Investig Agric Curr Res 3(2).

19. KF Dossa, YES Miassi (2018) Socio-Economic Influencing Factors Adoption of Organic Cotton in North-East Benin: Case of Kandi Commune. Int J Progress Sci Technol 6(2): 577-584.

20. PAdegbola, A Aloukoutou, B Diallo (2011) Analysis of the competitiveness of local maize in Benin. Program of Strengthening and Research on Food Security in West Africa (PRESAO) Component SRAI.
21. AJ Yabi, S Tovignan, R Moustafa (2012) Analysis of maize production and supply for food security improvement in the Borgou region in Northeast of Benin. Afr J Agric Res 8(11): 943-951.

22. EG Achigan Dako, AC Houdegbe, M Glele R Nono Womdim (2014) Analysis of the Maize Seed Production and Distribution System (Zea mays L.) in South Benin. Biotechnol Agron Soc Env flight 18(1): 49-60.

23. KF Dossa (2017) Adoption of organic cotton production in North Benin: Case of Kandi commune. bachelor's degree, University of Parakou, Faculty of Agronomy, Benin.

24. FUPRO-Benin (2011) Warrantage: Determinants for successful storage and credit of maize in Benin.

25. P Agbohessi, I Imorou Toko, J Yabi, J Dassoundo Assogba, P Kestemont (2011) Characterization of chemical pesticides used in cotton production and impact on economic indicators in the Banikoara Commune in the north of Benin. Int J Biol Chem Sci 5: 1828-1841.

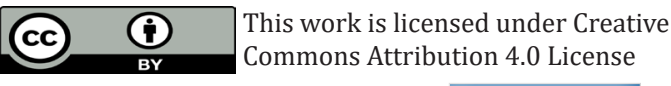

To Submit Your Article Click Here: Submit Article

DOI: $10.32474 /$ CIACR.2018.04.000176

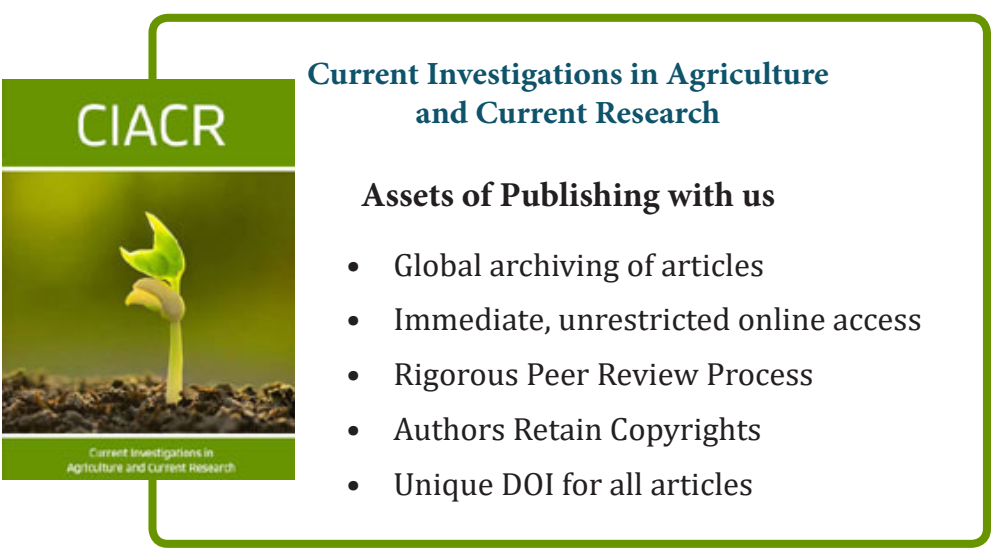

